\title{
Mass balances of major solutes, nutrients and particulate matter as water moves through the floodplains of the Pantanal (Paraguay River, Brazil)
}

\section{Balanço de massa de solutos dissolvidos e particulados na planície do Pantanal (Rio Paraguai), Brasil.}

\author{
Marcia Divina de Oliveira1, Debora Fernandes Calheiros ${ }^{2}$ and Stephen Kimber Hamilton ${ }^{3}$ \\ ${ }^{1}$ Embrapa Pantanal, Corumbá, MS, Brasil \\ ${ }^{2}$ Instituto de Saúde Coletiva, Universidade Federal de Mato Grosso, Cuiabá, MT, Brasil \\ ${ }^{3}$ W.K. Kellogg Biological Station, Departament of Zoology, Michigan State University, Hickory Corners, Michigan, USA \\ E-mails: marcia.divina@embrapa.br(MDO), calheirosdebora@gmail.com (DFC),hamilton@kbs.msu.edu (SKH)
}

Received: October 20, 2017 - Revised: June 18, 2018 - Accepted: August 07, 2018

\begin{abstract}
In the upper Paraguay River basin, which includes the Pantanal, one of the largest wetlands in the world, rivers connection the surrounding upland plateaus with lowland floodplains. Agriculture, erosion, urban effluent, and hydropower in the uplands can alter the transport of materials by rivers to the Pantanal. Information about material transport, particularly nutrients, is still insufficient to evaluate changes. In this study we estimated rates of dissolved and suspended material transport from the upland watersheds into the Pantanal, and through the Paraguay River, and calculated mass balances of these flows to reveal net losses and gains inside the Pantanal. We sampled fifteen tributaries and the Paraguay River for seven years. The annual water balance in the basin was almost complete, with a deficit of only 11\%. Predicted:Observed ratios close to one indicated a near balance between inputs and outputs for dissolved solutes and nutrients, however sedimentation losses of suspended solids and particulate carbon were significant. In spite of a high degree of river-floodplain contact, no significant changes on solutes concentrations were observed between inputs and outputs, enough to alter the transport of solutes though the Pantanal, indicating equilibrium in biogeochemical process on floodplain.
\end{abstract}

Keywords: Nutrients; Major ions; Solutes; Mass balance; Paraguay River; Pantanal Wetland.

\section{RESUMO}

Na Bacia do Alto Paraguai, formadora do Pantanal Mato-grossense, uma das maiores áreas úmidas do mundo, os rios fazem a conexão entre o planalto e a extensa planície de inundação. Agropecuária, potencial erosivo associado a desmatamento elevado, efluentes urbanos e dezenas de barramentos hidrelétricos no planalto podem alterar o transporte de matéria e energia para a planície. Contudo o conhecimento sobre o transporte, principalmente de nutrientes, ainda é insuficiente para avaliar potenciais alterações. Neste estudo foi estimado o carreamento de materiais dissolvidos e em suspensão do planalto para o Pantanal e no seu exutório, o rio Paraguai, avaliando os fluxos e balanços de massa. O rio Paraguai e tributários foram amostrados durante sete anos, com frequência semestral ou mensal. O balanço hidrológico anual do Pantanal foi considerado quase completo, com déficit de apenas 11\%, entre entrada e saída. A relação Previsto: Observado também indicou um balanço de massa praticamente completo para solutos dissolvidos e nutrientes, porém, com perdas significativas para sólidos suspensos e carbono. Apesar da extensa área de interação rios-planície, não foram observadas mudanças nas concentrações dos solutos suficientes para modificar o transporte de solutos através do Pantanal, o que indica equilíbrio entre os processos biogeoquímicos na planície.

Palavras-chave: Nutrientes; Solutos dissolvidos; Sólidos suspensos; Balanço de massa; Rio Paraguai; Pantanal. 
Mass balances of major solutes, nutrients and particulate matter as water moves through the floodplains of the Pantanal (Paraguay River, Brazil)

\section{INTRODUCTION}

The upper Paraguay River and its tributaries originate in surrounding plateaus of elevations around $800 \mathrm{~m}$ before descending to lower elevations of around $200 \mathrm{~m}$ where the rivers pass through vast floodplains lying on alluvial sediments. The floodplains, which occupy an area of $140,000 \mathrm{~km}^{2}$, include permanently and seasonally flooded lands, and the overall region is known as the Pantanal Mato-Grossense. The longest inundation hydroperiods occur in the lowermost reaches of the tributaries and along the Paraguay River within the Pantanal (PADOVANI, 2010). The Pantanal is a region of national and international importance, lying mostly in Brazil but extending into Bolivia and Paraguay, and is recognized as one of the most extensive floodplains in the world (JUNK et al., 2006; CALHEIROS; OLIVEIRA, 2010). The rivers and floodplains of the basin provide many ecosystem services (WANTZEN et al., 2008; CALHEIROS et al., 2012), sustaining economic activities both in the plateau area (agriculture, agroindustry, and urban areas) and on the floodplains (extensive grazing by livestock on native pastures, fishing, tourism, and food security for communities and traditional peoples).

The rivers of the basin transport massive quantities of sediments from the plateaus to the floodplains of the Pantanal, amounting to 29,000 t/day, principally via the Taquari and São Lourenço drainage basins (SEMMELMANN et al., 1996; Barbedo, 2003). The transported sediments tend to accumulate as river water first enters the flooded areas, forming alluvial fans that are readily observed in satellite images of the Pantanal (ASSINE; SOARES, 2004; ZANI et al., 2009). The Taquari River region has the most sediment accumulation, forming one of the world's largest active alluvial fans. Recent changes in the course of the river due to sediment deposition on the alluvial fan have been documented by Padovani et al. (2005), who estimated that approximately $77 \%$ of the sediment load of the Taquari River is deposited on the floodplains. Other tributaries including the São Lourenço, Vermelho, Itiquira, Correntes, Aquidauana and Miranda rivers also display sedimentation and geomorphological changes within the Pantanal, although they have been less studied.

The loads of solutes, carbon, and nutrients remain little known for the majority of the rivers of the basin. Oliveira and Calheiros (1998) estimated the transport of nitrogen, phosphorus, and suspended solids and their losses on the floodplains of the Taquari River. Moreira et al. (2005), Moreira et al. (2007) and Silva et al. (2007) estimated loads of the Jauru, Sepotuba, Cabaçal, Cuiabá, São Lourenço, Correntes and Piquiri rivers, reporting maximum and minimum values and noting an increase in loads during the rainy season. The increase in nutrient loads of the Cuiabá River downstream of the Cuiabá/Várzea Grande urban zone and its implications for the Pantanal were studied by Zeilhofer et al. (2006, 2016). Fantin-Cruz et al. (2015) and Fantin Cruz et al. (2016) observed changes in river water quality due to hydroelectric dams on the Itiquira and Correntes rivers.

Information on the biogeochemistry of the Upper Paraguay River basin is also provided by Rezende Filho et al. (2012), who analyzed the chemical composition and seasonality of solutes in the main rivers at their points of entry into the Pantanal, as well as by Hamilton et al. (1997), who estimated the water and solute mass balance for the Pantanal, albeit with low spatial and temporal resolution of sampling for a number of the rivers. Characteristics of the Paraguay River and its interaction with the floodplains, including the flood pulse and seasonal anoxic events are described by Hamilton et al. (1995, 1997), Calheiros and Hamilton (1998), Calheiros (2003), and Oliveira et al. (2011), among others. The complexity of biogeochemical cycling within the floodplain is also shown in studies by Vega et al. (2014), considering carbon stocks in comparison to the Orinoco, by Johnson et al. (2013), Liengaard et al. (2013) and Souza et al. (2012) on $\mathrm{CO}_{2}$ and $\mathrm{N}_{2} \mathrm{O}$ dynamics in seasonally flooded areas, and Hamilton et al. (1995) and Bastviken et al. (2010) on $\mathrm{CH}_{4}$ production on the floodplains. These are relevant studies, but they were conducted on smaller spatial scales, and do not speak to the complexity of the overall Pantanal region.

In this region with such extensive river-floodplain interactions (JUNK et al. 1989; HAMILTON et al. 1997), including seasonal inundation with large inputs of allochthonous material, it would not be expected that input and outputs of solutes would be in balance. There are numerous hydrological and biogeochemical processes that could potentially affect the solute fluxes. In addition to sedimentation on the floodplains, nutrient transformations are expected to be important due to the high levels of biological activity on the floodplain, as well as additions of solutes from the chemical weathering of deposited sediments.

Given the expected importance of processes that retain, transform, or add solutes and particulate matter as water moves through the Pantanal, the objective of this study was to evaluate the transfer of dissolved and particulate material from the plateau to the floodplains via fluvial transport, and to calculate the mass balance of these materials between the entry of rivers into the Pantanal and the exit of the Paraguay River from the Pantanal at Porto Esperança. We emphasize nutrients because these have not been comprehensively studied in the Pantanal. Although the mass balance for major solutes estimated by Hamilton et al. (1997) was nearly complete and indicated little influence of the floodplains on riverine fluxes, their calculations were preliminary, based on few samplings of rivers entering the Pantanal, especially in the northern part. In this study we analyze a spatially and temporally broader set of samplings, thereby increasing our ability to detect differences between the inflow and outflow fluxes, and we also include nutrients and suspended solids in our analysis.

The results of this study broaden our understanding of the dynamics of solutes and particulate matter in rivers with extensive floodplains, which are recognized as altering fluvial transport of biogeochemically important materials. The Pantanal region has been compared with other large floodplains such as the Orinoco, Okavango, and Amazon (JUNK et al., 2006), in which elemental transport through the catchments has been studied, as have the effects of the floodplains on river biogeochemistry. This study also contributes to the knowledge needed to evaluate the impacts of human activities, particularly the potential future construction of hydroelectric dams that could amount to 180 projects, compared to just 16 in operation in 2007 (ANEEL, 2016). Studies by Zeilhofer and Moura (2009) and Souza et al. (2009) showed hydrological alterations in the Cuiabá River after 2000 due to the construction of the Manso dam and reservoir, but they did not find effects $400 \mathrm{~km}$ downstream. Although small hydropower dams $(<30 \mathrm{MW})$ are the 
most abundant, the cumulative and synergistic effects of all of these dams have the potential to alter the balance of solutes and suspended particulate matter carried by rivers through the Pantanal.

\section{MATERIALS AND METHODS}

\section{Study site}

The hydrographic basin of the upper Paraguay River drains $1,095,000 \mathrm{~km}^{2}$, of which $33 \%$ is in Brazil and the remainder is in Bolívia, Paraguay and Argentina. The Paraguay River is borne in the extreme north of the basin, near the boundary with the Amazon River catchment, and flows about $80 \mathrm{~km}$ before entering the Pantanal. Within the Brazilian Pantanal the river flows across extensive floodplains, exiting the Pantanal at the confluence with the Apa River along the Paraguayan border, 2,621 km downstream of its origin.

This study considers the $240,000 \mathrm{~km}^{2}$ of the upper Paraguay River basin above Porto Esperança, which includes the majority of the Brazilian Pantanal, a $140,000-\mathrm{km}^{2}$ area subject to seasonal inundation by riverine overflow as well as slow drainage of local rainfall (Figure 1).

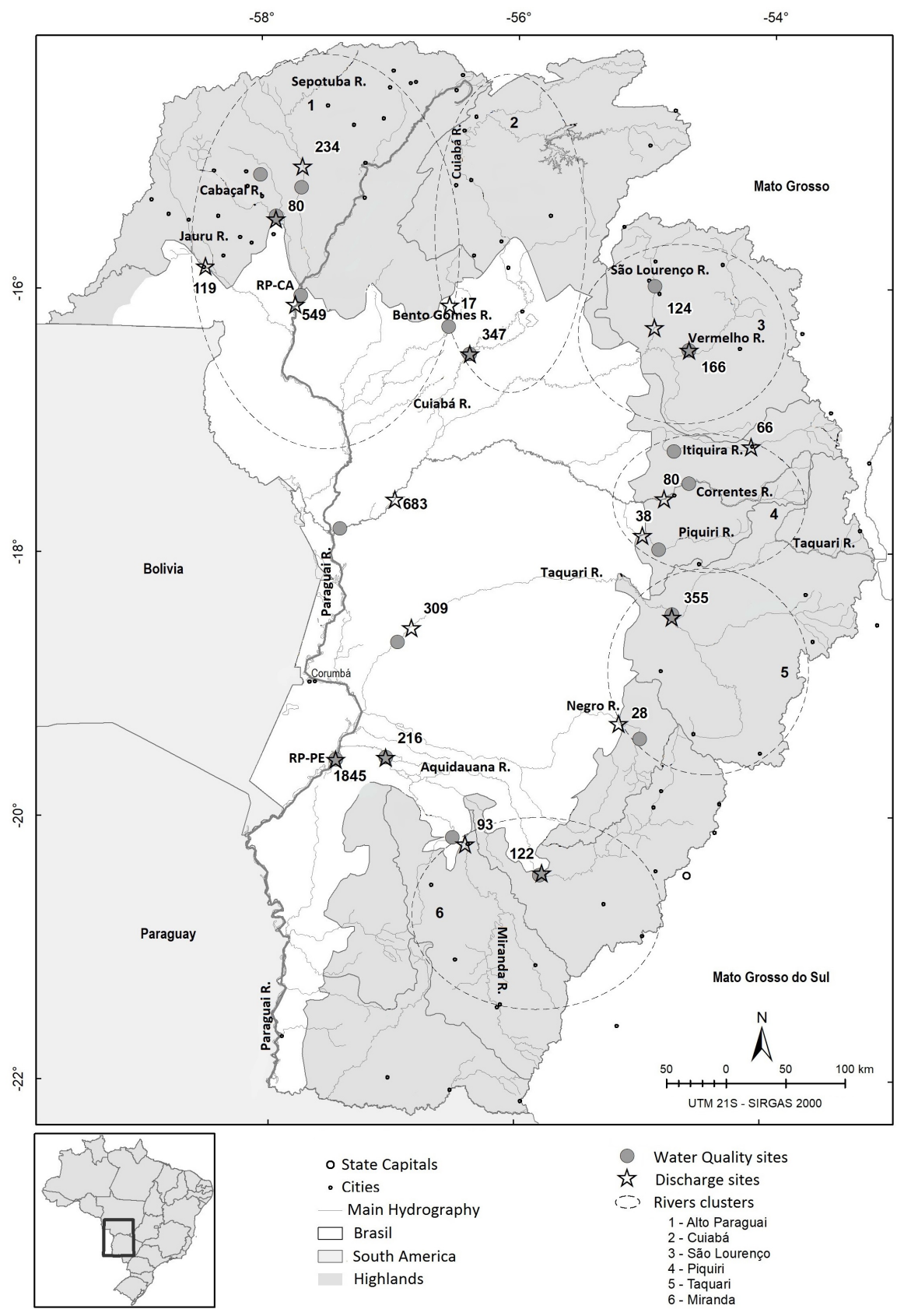

Figure 1. Drainage basin of the Paraguay River, with details of the Brazilian portion, locations of discharge monitoring stations, mean discharges $\left(\mathrm{m}^{3} / \mathrm{s}\right)$ during the study period, and water quality sampling locations. Circles show the six river clusters discussed in this study. RP-CA = Paraguay River at Cáceres and RP-PE = Paraguay River at Porto Esperança. 
Mass balances of major solutes, nutrients and particulate matter as water moves through the floodplains of the Pantanal (Paraguay River, Brazil)

The river network draining the basin above Porto Esperança includes the principal tributaries directly flowing into the Paraguay River, including the Jauru, Cabaçal, Sepotuba, Cuiabá, Taquari, Miranda, and Apa rivers, as well as other tributaries that bring water into the Pantanal but not directly in the Paraguay River, including the Itiquira, Correntes, Piquiri, Negro, and Aquidauana rivers. In this study we refer to all of these rivers as tributaries. The Paraguay River is the principal river of a depositional system characterized by the presence of megafans constructed by its tributaries. Assine and Soares (2004) and Zani et al. (2009) identified six alluvial fans in the Pantanal: one along the Paraguay River below the city of Cáceres and the others along the Cuiabá, São Lourenço, Taquari, Negro and Miranda rivers. Many of the rivers in the Pantanal display distributary drainage, as for example the Taquari River, as well as the upper Paraguay River in the region that forms the Corixo Grande alluvial fan, downstream of Cáceres.

In the dry season, the rivers of the plateau are fed by aquifers that yield different water quality between the northern and southern parts of the basin. The major aquifers in the northern basin including the Cuiabá River are known as Fraturado Centro-Sul and Ponta Grossa. The Guarani and Bauru aquifers occur in the basin of the São Lourenço and Piquiri rivers and contain relatively acidic waters. The Guarani aquifer, which also extends through the Taquari River basin to the Miranda River basin, contains water with a mean conductivity of $165 \mu \mathrm{S} / \mathrm{cm}$ and a $\mathrm{pH}$ near neutral. The differences in water quality among these aquifers are small; sodium, calcium, and bicarbonate dominate the major ions. Calcium and magnesium concentrations increase a little in the Serra Geral aquifer in the Miranda River basin. Some groundwaters contain elevated concentrations of iron, such as the Fraturado Centro-Sul, whose waters originate in the São Lourenço and Vermelho river basins.

Mean annual rainfall ranges from 800-2,000 mm, with higher amounts in the plateau regions, particularly in the extreme northern areas. Despite the lower rainfall in the southern part, it is more equally distributed throughout the year. The rainy season occurs from October to April; the remainder of the year is the dry season. Mean annual total evapotranspiration (ET) is 1,239 mm, with the highest rates occurring in August, the month with highest solar irradiance. Despite uncertainties in the estimation of ET, researchers estimate that ET and rainfall are approximately in balance within the Pantanal, or that ET is slightly higher than rainfall (HAMILTON et al., 1997; PENATTI et al., 2015).

Cattle grazing and crops are the predominant land uses in the basin, with grazing the main driver of conversion of natural areas for human use, amounting to $12 \%$ of the floodplains and $44 \%$ of the plateau areas (INSTITUTO SOS PANTANAL; WWF-BRASIL, 2015). Removal of native vegetation as well as agricultural activities in the plateau areas have increased erosion rates and the consequent entry of suspended sediments into the alluvial fans, rapidly changing the fluvial landscape, as exemplified by the Taquari River (ASSINE, 2005). In addition to agriculture and livestock (cattle, poultry, and hogs), water is also used for irrigation, which has been increasing each year (ANA, 2017).

Approximately 1.9 million people live in the basin, which is $1 \%$ of the population of Brazil, and $84.7 \%$ inhabit urban areas, especially in the cities of Cuiabá (483,000 inhabitants),
Várzea Grande, (215,000) and Rondonópolis (150,000), all major population centers on the plateau in the state of Mato Grosso. Discharges of nutrients and coliforms into the Cuiabá River from the urban zones of Várzea Grande and Cuiabá have been reported by Zeilhofer and Moura (2009).

\section{Water sampling and analysis}

In addition to the Paraguay River, we sampled the 14 largest tributaries: the Sepotuba, Cabaçal, Jauru, Bento Gomes, Cuiabá, São Lourenço, Vermelho, Piquiri, Itiquira, Correntes, Taquari, Negro, Miranda, and Aquidauana rivers. The Cuiabá, Taquari and Miranda rivers were sampled on the plateau or close to the boundary between the plateau and the floodplains (representing entry into the floodplains) as well as near their mouths. The Paraguay River was sampled in the north at Cáceres (RP-CA in Figure 1) to represent entry into the floodplains, and at Porto Esperança (RP-PE) to represent the drainage of water from the study area. The area drained by each tributary, its location, identification, the period of discharge records, and the location of water sampling stations are given in Table 1.

Rivers in the plateau areas were sampled twice per year, in the dry and wet seasons, from 2000-2007 (16 samplings). Within the floodplains, the rivers were sampled near their mouths either monthly (Miranda River), or every 2-3 months (Cuiabá and Taquari rivers). The Cuiabá, Taquari and Miranda rivers within the floodplains were thus sampled 26, 40, and 91 times, respectively. The Paraguay River was sampled 16 times at Cáceres and 91 times at Porto Esperança.

A standardized protocol was used for water sample collection in which $9 \mathrm{~L}$ was obtained with a Van Dorn sampler from $60 \%$ of the water column depth, mixing samples from three equally spaced points across the channel in a bucket and subsampling the mixture while agitating it. A 5-L subsample for analysis of suspended solids was passed through a $62 \mu \mathrm{m}$ sieve before particulate matter was collected on a glass fiber filter (pore size, $1.2 \mu \mathrm{m}$ ) for gravimetric analysis (APHA, 2005). Specific conductivity (COND, corrected to $25^{\circ} \mathrm{C}$ ) and $\mathrm{pH}$ were measured in the field. Concentrations of major cations and anions, silica (Si), and total iron (FeT), Chloride were measured following APHA (2005). Particulate organic carbon (POC) was analyzed by platinum-catalyzed combustion and gas chromatography with a Shimadzu TOC 5000 analyzer. Dissolved organic carbon (DOC) was analyzed following Benner and Strom (1993).

Major cations $\left(\mathrm{Ca}^{2+}, \mathrm{Mg}^{2+}, \mathrm{Na}^{+}\right.$and $\left.\mathrm{K}^{+}\right)$were measured by flame atomic absorption spectrometry. Gran titrations of total alkalinity provided an approximation of $\mathrm{HCO}_{3}^{-}$concentrations. Major cations and anions were summed to estimate total dissolved solute (DS).

Total nitrogen (TN) and dissolved inorganic N (TDN) were analyzed following Wetzel and Likens (1991) and Valderrama (1981), using a flow injection system. Total phosphorus (TP) and dissolved reactive P (DP) were analyzed following Mackereth et al. (1978) and Wetzel and Likens (1991). 
Table 1. Principal rivers, their drainage areas, identification (ANA/HIDROWEB code) and information on the fluviometric stations, and the location of water chemistry sampling stations in the upper Paraguay River basin.

\begin{tabular}{|c|c|c|c|c|c|c|c|c|}
\hline \multirow[b]{2}{*}{ Sites } & \multirow[b]{2}{*}{ Abbrevation } & \multirow[b]{2}{*}{$\begin{array}{c}\text { Drainage } \\
\text { basin area } \\
(\mathrm{Km} 2)^{*}\end{array}$} & \multicolumn{4}{|c|}{ Discharge measurement sites } & \multicolumn{2}{|c|}{ Water sampling sites } \\
\hline & & & $\begin{array}{c}\text { ANA } \\
\text { monitoring } \\
\text { station } \\
\text { code* }\end{array}$ & $\begin{array}{l}\text { Period of } \\
\text { data }\end{array}$ & Latitude & Longitude & Latitude & Longitude \\
\hline Jauru & JAU & 5,8390 & 66072000 & $2000-2007$ & $15^{\circ} 51^{\prime} 00^{\prime \prime}$ & $58^{\circ} 27^{\prime} 00^{\prime \prime}$ & $16^{\circ} 08^{\prime} 82^{\prime \prime}$ & $58^{\circ} 00^{\prime} 56^{\prime \prime}$ \\
\hline Cabaçal & $\mathrm{CAB}$ & 3,6070 & 66065000 & $2000-2007$ & $15^{\circ} 28^{\prime} 96^{\prime \prime}$ & $57^{\circ} 53^{\prime} 37^{\prime \prime}$ & $15^{\circ} 821 ”$ & $57^{\circ} 53^{\prime} 47^{\prime \prime}$ \\
\hline Sepotuba & SEP & 8,2760 & 66055000 & $2000-2007$ & $15^{\circ} 05^{\prime} 36^{\prime \prime}$ & $57^{\circ} 41^{\prime} 04^{\prime \prime}$ & $15^{\circ} 14^{\prime} 80^{\prime \prime}$ & $57^{\circ} 41^{\prime} 49^{\prime \prime}$ \\
\hline Bento Gomes & BGO & 2,9100 & 66110000 & $1998-2005$ & $16^{\circ} 8^{\prime} 57^{\prime \prime}$ & $56^{\circ} 32^{\prime} 39^{\prime \prime}$ & $16^{\circ} 18^{\prime} 57^{\prime \prime}$ & $56^{\circ} 32^{\prime} 39^{\prime \prime}$ \\
\hline Cuiabá & CUI & 35,3100 & 66340000 & $2000-2007$ & $16^{\circ} 31^{\prime} 13^{\prime \prime}$ & $56^{\circ} 22^{\prime} 32^{\prime \prime}$ & $16^{\circ} 30^{\prime} 80^{\prime \prime}$ & $56^{\circ} 2 ’ 39^{\prime \prime}$ \\
\hline São Lourenço & SLO & 7,2010 & 66400000 & 1999-2006 & $16^{\circ} 18^{\prime} 39$ & $54^{\circ} 55^{\prime} 22$ & $15^{\circ} 59^{\prime} 54^{\prime \prime}$ & $54^{\circ} 55^{\prime} 22^{\prime \prime}$ \\
\hline Rio Vermelho & VER & 12,2690 & 66450001 & $2000-2007$ & $16^{\circ} 28^{\prime} 44^{\prime \prime}$ & $54^{\circ} 39^{\prime} 02^{\prime \prime}$ & $16^{\circ} 28^{\prime} 53^{\prime \prime}$ & $54^{\circ} 39^{\prime} 12^{\prime \prime}$ \\
\hline Itiquira & ITI & 2,9220 & 66520000 & $2000-2007$ & $17^{\circ} 12^{\prime} 28^{\prime \prime}$ & $54^{\circ} 09^{\prime} 04^{\prime \prime}$ & $17^{\circ} 5^{\prime} 5^{\prime \prime}$ & $54^{\circ} 45^{\prime} 42^{\prime \prime}$ \\
\hline Correntes & COR & 4,0200 & 66490000 & 1999-2006 & $17^{\circ} 36^{\prime} 39^{\prime \prime}$ & $54^{\circ} 49^{\prime} 57^{\prime \prime}$ & $17^{\circ} 29^{\prime} 41$ & $54^{\circ} 38^{\prime} 21$ \\
\hline Piquiri & PIQ & 2,7270 & 66480000 & 1984-1991 & $17^{\circ} 53^{\prime} 21^{\prime \prime}$ & $55^{\circ} 00^{\prime} 12^{\prime \prime}$ & $17^{\circ} 59^{\prime} 51^{\prime \prime}$ & $54^{\circ} 52^{\prime} 24^{\prime \prime}$ \\
\hline Taquari & TAQ & 27,6280 & 66870000 & $2000-2007$ & $18^{\circ} 30^{\prime} 28^{\prime \prime}$ & $54^{\circ} 45^{\prime} 43^{\prime \prime}$ & $18^{\circ} 29^{\prime} 18^{\prime \prime}$ & $54^{\circ} 45^{\prime} 38^{\prime \prime}$ \\
\hline Negro & NEG & 1,0430 & 66886000 & 1979-1994 & $19^{\circ} 19^{\prime} 06^{\prime \prime}$ & $55^{\circ} 10^{\prime} 27^{\prime \prime}$ & $19^{\circ} 26^{\prime} 10^{\prime \prime}$ & $55^{\circ} 0 ’ 20^{\prime \prime}$ \\
\hline Aquidauana & $\mathrm{AQU}$ & 15,8600 & 66945000 & $2000-2007$ & $20^{\circ} 27^{\prime} 31^{\prime \prime}$ & $55^{\circ} 46^{\prime} 51^{\prime \prime}$ & $20^{\circ} 28^{\prime} 40^{\prime \prime}$ & $55^{\circ} 48^{\prime} 10^{\prime \prime}$ \\
\hline Miranda & MIR & 14,4960 & 66910000 & 1999-2006 & $20^{\circ} 14^{\prime} 27^{\prime \prime}$ & $56^{\circ} 23^{\prime} 57^{\prime \prime}$ & $20^{\circ} 11^{\prime} 36^{\prime \prime}$ & $56^{\circ} 30^{\prime} 17^{\prime \prime}$ \\
\hline Cuiabá-at mouth & CUI2 & 104,0020 & 66750000 & $2000-2007$ & $17^{\circ} 37^{\prime} 24^{\prime \prime}$ & $56^{\circ} 57^{\prime} 54^{\prime \prime}$ & $17^{\circ} 50^{\prime} 48^{\prime \prime}$ & $57^{\circ} 24^{\prime} 04^{\prime \prime}$ \\
\hline Taquari-at mouth & TAQ2 & 31,2000 & 66885000 & $1968-1993$ & $18^{\circ} 36^{\prime} 00^{\prime \prime}$ & $56^{\circ} 50^{\prime} 00^{\prime \prime}$ & $18^{\circ} 42^{\prime} 40^{\prime \prime}$ & $56^{\circ} 56^{\prime} 38^{\prime \prime}$ \\
\hline Miranda -at mouth & MIR2 & 44,7400 & $6691+6695$ & $1999-2006$ & & & $19^{\circ} 34^{\prime} 65^{\prime \prime}$ & $57^{\circ} 02^{\prime} 19^{\prime \prime}$ \\
\hline Paraguay-Cáceres & RP-CA & 31,5700 & 66070004 & $2000-2007$ & $16^{\circ} 08^{\prime} 36$ & $57^{\circ} 44^{\prime} 44$ & $16^{\circ} 04^{\prime} 28^{\prime \prime}$ & $57^{\circ} 42^{\prime} 14^{\prime \prime}$ \\
\hline Paraguay - Amolar & RP-AM & 234,0000 & 66800000 & 1999-2006 & $18^{\circ} 02^{\prime} 19^{\prime \prime}$ & $57^{\circ} 29^{\prime} 19^{\prime \prime}$ & $18^{\circ} 05^{\prime} 10^{\prime \prime}$ & $57^{\circ} 28^{\prime} 29^{\prime \prime}$ \\
\hline Paraguay -Porto Esperança & RP-PE & 363,0000 & 66960008 & $2000-2007$ & $19^{\circ} 36^{\prime} 02^{\prime \prime}$ & $57^{\circ} 26^{\prime} 14^{\prime \prime}$ & $19^{\circ} 36^{\prime} 02^{\prime \prime}$ & $57^{\circ} 26^{\prime} 14^{\prime \prime}$ \\
\hline
\end{tabular}

\section{Hydrological transport}

Mean concentrations were weighted by discharge using the formula: Cweighted (mg/l) $=\sum$ mean monthly loads (mg/month) $/ \Sigma$ mean monthly discharge (L/month). Daily and annual loads were estimated by multiplying concentration by discharge.

Discharge data (in $\mathrm{m}^{3} / \mathrm{s}$ ) were obtained from the HIDROWEB system of the Brazilian Agência Nacional de Águas (ANA). As shown in Table 1, in some cases the water sampling stations did not coincide with discharge stations, in which case we used the closest discharge station. The estimates of loads within the floodplains are more uncertain because there are fewer discharge stations, and a number of them have shorter records and are no longer in operation. Whenever possible discharge data from the day of sampling was used to estimate loads; when that was not available the monthly mean discharge for the past 10 years corresponding to the month of sampling was used.

The Aquidauana River flows into the Miranda River a short distance above the confluence of the Miranda and Paraguay rivers, and therefore the discharges for stations on the Aquidauana (ANA 669500) and Miranda (669200) were summed to estimate discharge of the Miranda River at its mouth. The Cuiabá River lacks a discharge station near its mouth, but measurements made during water sampling showed discharge to be similar to an upriver station (66750000), and therefore the long-term record of the upriver station was used to represent the discharge of that river at its mouth.
For the Paraguay River at Porto Esperança there are no discharge data after 1981; only water level has been measured since then. Correia (2016) constructed a stage-discharge rating curve using the data from 1965-1973, although that was a particularly dry period in the Pantanal. To estimate discharge during the period of this study, a rating curve was constructed based on stage and discharge measurements taken from 1975-1981 and equations 1 and 2 below (Collischon, W., personal communication). Above a stage around $520 \mathrm{~cm}$ a change in the stage-discharge relation was observed, likely due to the inundation of adjacent floodplain. Therefore Equation (1) was used for stages up to $520 \mathrm{~cm}$ and Equation (2) for higher stages:

$Q=0,0069 * h^{2}+1,1292 * h+1096$

$Q=0,0656 * h^{2}-56,042 * h+14956$

where $Q$ is discharge in $\mathrm{m} 3 / \mathrm{s}$ and $b$ is the stage in $\mathrm{cm}$.

Loads carried by the tributaries were analyzed by region within the basin as follows: 1- Upper Paraguay (Paraguay River at Cáceres, plus the Sepotuba and Cabaçal rivers entering above Cáceres and the Jauru and Bento Gomes rivers entering below Cáceres) 2- Cuiabá (Cuiabá River above the São Lourenço River), 3- São Lourenço (São Lourenço and Vermelho rivers) 4- Piquiri (Piquiri, Itiquira and Correntes rivers), 5- Taquari (Taquari and Negro rivers) and 6- Miranda (Miranda and Aquidauana rivers) (Figure 1). 
To compare loads of the Cuiabá, Taquari and Miranda rivers above and below their floodplain reaches, a simplified mass balance for water, solutes, and suspended solids was calculated from the mean discharge and the loads measured on each sampling date. The annual mass balance for the entire Pantanal was expressed as a comparison of the discharge-weighted mean concentration for the sum of the tributary inputs to the discharge-weighted mean concentration of the Paraguay River outflow at Porto Esperança (site RP-PE). When monthly measurements of water chemistry from throughout the year were not available, the means of the daily loads based on available samplings were multiplied by 365 to estimate annual loads.

The total inputs into the Pantanal were calculated as loading (i.e., t/d) from both rain falling directly on the Pantanal as well as river transport from the plateau areas. Chemistry of rainfall was not available for the upper Paraguay River basin, so a study from Amazonia was used (HONÓRIO et al., 2010). Although that study measured rain chemistry at considerable distance from the Pantanal, their site represents the chemistry of rain in low-elevation, continental areas far from maritime or Andean influence, and hence provides a reasonable estimate for the upper Paraguay River basin. In addition, the majority of rainfall in the Pantanal originates as water vapor from the Amazon basin (BERGIER et al., 2018).

To calculate loading from rainfall, the solute concentrations from Honório et al. (2010) were multiplied by the mean annual rainfall on the inundated portion of the Pantanal, based on inundation area from 2000-2007 estimated with satellite remote sensing by Padovani (2010).

The mass balance was examined using the ratio of Predicted:Observed (P:O) for loads or concentrations. Observed values are those measured at the Paraguay River outflow at Porto Esperança (RP-PE site). Predicted values for RP-PE are based on the total inputs (tributaries plus rainfall on inundated land).
To express the predicted value as a volume-weighted mean concentration, total input loads were divided by the output of water at Porto Esperança.

\section{RESULTS AND DISCUSSION}

\section{Concentrations of major solutes, nutrients, and suspended solids in the principal tributaries of the Paraguay River draining the plateau areas}

The mean $\mathrm{pH}$ values of the tributaries were circumneutral in the northern part of the upper Paraguay River basin (except for the Sepotuba River), more acidic in the central part, and more alkaline in the southern part. The specific conductivity (COND) also was lower in the central part of the basin (Table 2). In the southern part, the Miranda River was more alkaline, with higher $\mathrm{pH}, \mathrm{COND}$, and dissolved solutes (SD), reflecting the influence of groundwaters of the Serra Geral aquifer, which are elevated in $\mathrm{Ca}^{2+}, \mathrm{Mg}^{2+}$ and alkalinity.

The concentrations of silica were lowest in the Correntes River and highest in the Miranda and Aquidauana rivers. The mean concentrations of $\mathrm{Ca}^{2+}, \mathrm{Mg}^{2+}$ and $\mathrm{Si}$ observed in this study were similar to those reported by Hamilton et al. (1997) for the Paraguay River at Porto Esperança: $5.0 \mathrm{mg} / 1$ for $\mathrm{Ca}^{2+}, 2.4 \mathrm{mg} / 1$ for $\mathrm{Mg}^{2+}$ and $7.5 \mathrm{mg} / \mathrm{l}$ for Si.

The mean concentrations of dissolved organic carbon (DOC) (Table 2) varied from $2.5 \mathrm{mg} / \mathrm{L}$ in the Correntes River to 7.9 and $7.6 \mathrm{mg} / \mathrm{L}$ in the Bento Gomes and Cuiabá rivers, with most of the rivers carrying 3-6 mg/L. Dalmargo et al. (2013) reported concentrations around $7.4 \mathrm{mg} / \mathrm{L}$ in the Cuiabá River. These concentrations are similar to those in the Paraná River (1.8-10.6 mg/L) and its tributary the Ivinhema River (1.8-6.6 mg/L),

Table 2. Chemical characteristics of the main tributaries of the Paraguay River. Values are discharge-weighted means from the sampling carried out between 2000 and 2007.

\begin{tabular}{|c|c|c|c|c|c|c|c|c|c|c|c|c|c|}
\hline \multirow{2}{*}{ Site } & COND & $\mathrm{pH}$ & $\mathrm{Ca}^{2+}$ & $\mathrm{Mg}^{2+}$ & $\mathrm{Na}^{+}$ & $\mathbf{K}^{+}$ & $\mathrm{HCO}^{3-}$ & $\mathrm{Cl}^{-}$ & $\mathrm{SO}_{4}^{2-}$ & DS & Si & DOC & Fe'T \\
\hline & $\mu \mathrm{S} . \mathrm{cm}-1$ & & \multicolumn{11}{|c|}{$\mathrm{mg} / \mathrm{L}$} \\
\hline Sepotuba & 15.6 & 6.5 & 2.67 & 0.72 & 0.82 & 0.97 & 3.69 & 0.69 & 8.16 & 17.72 & 4.09 & 4.32 & 0.54 \\
\hline Cabaçal & 68.7 & 7.0 & 6.41 & 2.00 & 3.73 & 1.83 & 29.87 & 0.81 & 7.29 & 51.94 & 5.43 & 3.76 & 1.26 \\
\hline Jauru & 67.7 & 6.8 & 6.84 & 2.05 & 4.6 & 1.81 & 36.22 & 2.15 & 6.02 & 59.69 & 4.78 & 7.08 & 0.77 \\
\hline Bento & 75.3 & 6.7 & 3.14 & 2.11 & 2.46 & 1.59 & 22.79 & 1.20 & 10.99 & 44.28 & 3.75 & 7.92 & 0.85 \\
\hline \multicolumn{14}{|l|}{ Gomes } \\
\hline Cuiabá & 70.2 & 7.0 & 5.66 & 2.46 & 1.68 & 1.46 & 35.03 & 0.64 & 4.24 & 51.16 & 2.09 & 7.56 & 0.81 \\
\hline São & 20.7 & 6.4 & 2.77 & 0.97 & 1.42 & 1.53 & 4.97 & 0.57 & 4.80 & 17.03 & 2.72 & 4.39 & 2.31 \\
\hline \multicolumn{14}{|l|}{ Lourenço } \\
\hline Vermelho & 31.9 & 6.5 & 3.29 & 1.52 & 1.61 & 1.90 & 8.95 & 0.60 & 8.96 & 26.83 & 4.40 & 3.96 & 3.75 \\
\hline Itiquira & 14.2 & 6.2 & 2.74 & 0.71 & 0.50 & 0.91 & 4.98 & 1.09 & 2.62 & 13.55 & 4.04 & 5.67 & 1.00 \\
\hline Correntes & 4.1 & 5.4 & 0.97 & 0.19 & 0.36 & 0.41 & 0.54 & 0.96 & 3.56 & 6.99 & 0.99 & 2.50 & 0.25 \\
\hline Piquiri & 19.2 & 6.0 & 2.29 & 0.59 & 1.14 & 1.54 & 3.12 & 1.14 & 4.28 & 14.11 & 3.15 & 6.37 & 1.61 \\
\hline Taquari & 22.8 & 6.4 & 2.58 & 0.64 & 1.20 & 2.26 & 6.87 & 0.94 & 3.72 & 18.20 & 5.71 & 4.27 & 2.52 \\
\hline Negro & 24.3 & 6.4 & 2.00 & 0.71 & 1.22 & 3.22 & 4.59 & 1.26 & 5.82 & 18.83 & 3.53 & 5.86 & 1.24 \\
\hline Aquidauana & 65.5 & 7.1 & 6.77 & 2.38 & 2.34 & 2.69 & 37.73 & 0.82 & 5.48 & 58.21 & 6.90 & 5.83 & 2.40 \\
\hline Miranda & 225.3 & 7.8 & 28.61 & 7.97 & 2.41 & 2.19 & 139.76 & 1.07 & 9.22 & 191.22 & 5.69 & 4.80 & 2.20 \\
\hline Mean & 51.82 & 6.58 & 5.48 & 1.79 & 1.82 & 1.74 & 24.22 & 0.99 & 6.08 & 42.13 & 4.09 & 5.31 & 1.54 \\
\hline Std. Dev. & 55.98 & 0.57 & 6.92 & 1.94 & 1.20 & 0.72 & 36.07 & 0.40 & 2.49 & 46.73 & 1.58 & 1.57 & 0.97 \\
\hline
\end{tabular}


where there is intensive agricultural land use in the basin (TEIXEIRA et al., 2008).

The mean concentrations of particulate organic carbon (POC) were 4.4 and $5.9 \mathrm{mg} / \mathrm{L}$ in the Vermelho and Taquari rivers, reaching as high as $15 \mathrm{mg} / \mathrm{L}$ (Figure 2). In the São Lourenço, Piquiri and Aquidauana rivers the mean concentrations were close to $3.0 \mathrm{mg} / \mathrm{L}$, and the other rivers carried lower concentrations. Abreu (2016) found similar concentrations in the Cuiabá River, mostly between 2-2.5 mg/L, with much higher concentrations (12-19 mg/L) in floodplain areas along that river. The concentrations reported in this study are similar to those reported for the Orinoco River (2.1-7.8 mg/L: MORA et al., 2014), Amazon River (0.2-7.4 mg/L: MOREIRA-TURCQ et al., 2003), and the Paraná River (mean, $2.1 \mathrm{mg} / \mathrm{L}$ : DEPETRIS; PAOLINI 1991).

The mean concentrations of total $\mathrm{N}(\mathrm{TN})$ in most of the tributaries were between $0.3-0.5 \mathrm{mg} / \mathrm{L}$, except in the Itiquira and Correntes rivers where they were around $0.2 \mathrm{mg} / \mathrm{L}$ (Figure 3). The mean concentrations of total dissolved N (TDN) were around $0.1 \mathrm{mg} / \mathrm{L}$, being higher in the Vermelho, Taquari, Negro and Aquidauana rivers. As for NT, the lowest concentrations of TDN were observed in the Itiquira and Correntes rivers (Figure 3). Mean concentrations of total phosphorus (TP) in the tributaries were around $0.03-0.07 \mathrm{mg} / \mathrm{L}$, with a maximum observed value of $0.14 \mathrm{mg} / \mathrm{L}$. The highest median concentrations of PT and DP were measured in the Miranda and Aquidauana rivers and the lowest concentrations were found in the Correntes, Itiquira, and Sepotuba rivers (Figure 3).

Although Zeilhofer et al. (2006, 2016) and Lima et al. (2015) reported high concentrations of nutrients in the Cuiabá River, below the metropolitan zones, the concentrations of NT and PT reported in this study are lower when compared to tributaries of the Paraná River (CUNHA et al., 2010), around 3.0 and $0.5 \mathrm{mg} / \mathrm{L}$ for NT and PT, respectively. These rivers also drain basins with animal agriculture and urban development.

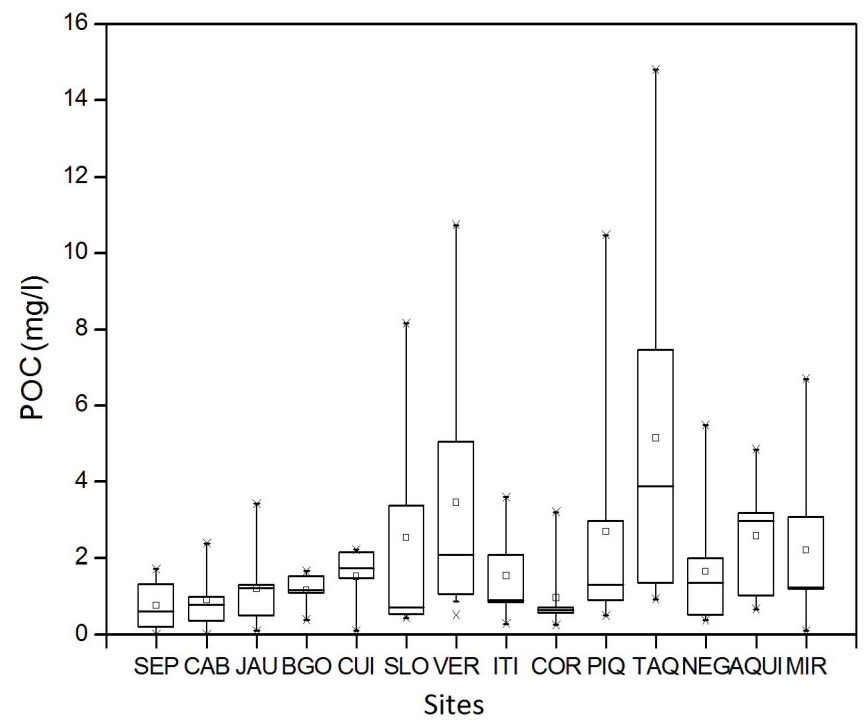

Figure 2. Concentrations of Particulate Organic Carbon (POC) ( $\mathrm{mg} / \mathrm{l})$ in tributaries of the Paraguay River, estimated twice per year from 2000-2007.
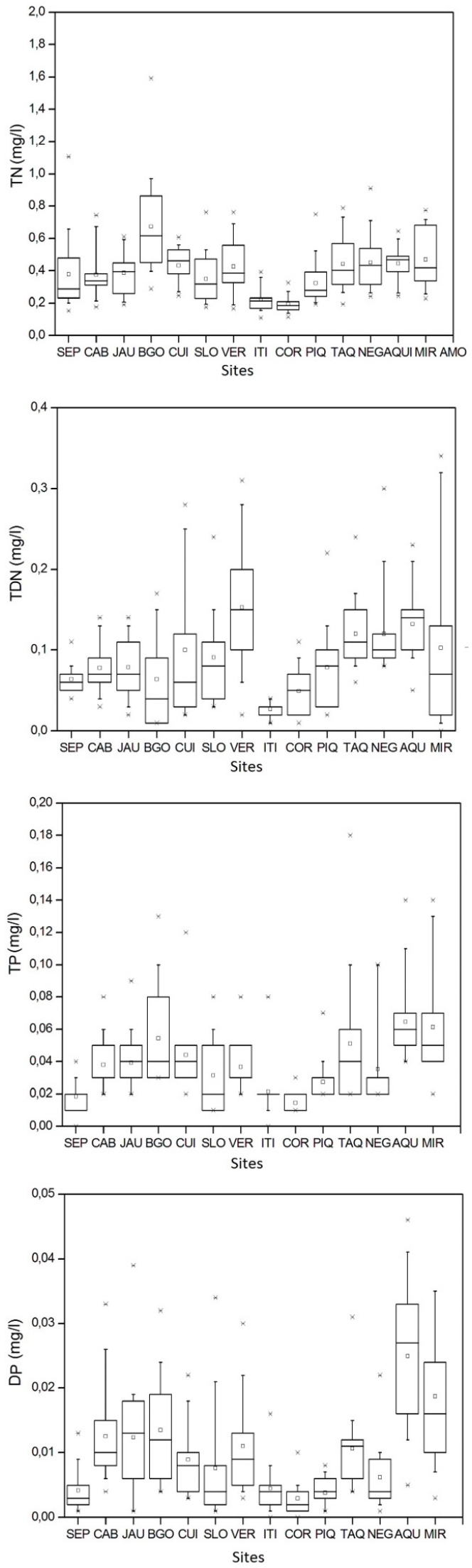

Figure 3. Concentrations of total nitrogen (TN), total dissolved nitrogen (TDN), total phosphorus (TP) and dissolved reactive phosphorus (DP) in tributaries of the Paraguay River, estimated twice per year from 2000-2007. 
Mass balances of major solutes, nutrients and particulate matter as water moves through the floodplains of the Pantanal (Paraguay River, Brazil)

Measurements of nutrient concentrations in the Paraguay River basin have been reported only recently, so the long-term means are not known.

The mean concentrations of total suspended solids (SS) were highest in the Vermelho and Taquari rivers $(154$ and $241 \mathrm{mg} / \mathrm{L}$, respectively), with maximum concentrations of $366 \mathrm{mg} / \mathrm{L}$ in the Vermelho and $810 \mathrm{mg} / \mathrm{L}$ in the Taquari (Figure 4). Mean concentrations in the Jauru, Sepotuba, Bento Gomes and Correntes rivers were between $5-20 \mathrm{mg} / \mathrm{L}$, with a maximum recorded concentration of $63 \mathrm{mg} / \mathrm{L}$.

The mean concentrations of SS in the Taquari River were 10-fold higher than in the Cuiabá River, reflecting the differences in erosion rates in these two regions, as has been reported for the baixada Cuiabana in the Cuiabá River basin by Pupim et al. (2015) and the Taquari River basin by Galdino (2012). Souza Filho (2013) concluded that since 1974 the increase in rainfall, together with higher overland runoff from agricultural land use intensification during the 1970s and 1980s, resulted in higher rates of erosion and sediment transport from the plateau areas than at present. Similar conclusions were reached by Padovani et al. (2005) for the Taquari River. Lima (2010), based on sampling from 1987-2000 during high discharge in the Cuiabá River below Cuiabá, estimated a mean SS concentration of $78 \mathrm{mg} / \mathrm{L}$. That estimate is lower than the $197 \mathrm{mg} / \mathrm{L}$ concentration estimated by Semmelmann et al. (1996) for the same station. In this study the mean concentration was about $50 \mathrm{mg} / \mathrm{L}$, with maximum concentrations below $100 \mathrm{mg} / \mathrm{L}$. Since its construction beginning in 2000, the Manso reservoir has reduced sediment export from that part of the upper Cuiabá River basin (CASONATTO, 2015).

Compared with the rivers of the Paraná River basin studied by Cunha et al. (2010), where SS concentrations were below $150 \mathrm{mg} / \mathrm{L}$ and the highest concentrations tended to occur in rivers draining land uses with more livestock and crops, some of the tributaries of the upper Paraguay River had much higher SS concentrations. The lower Orinoco River at Ciudad Bolivar also

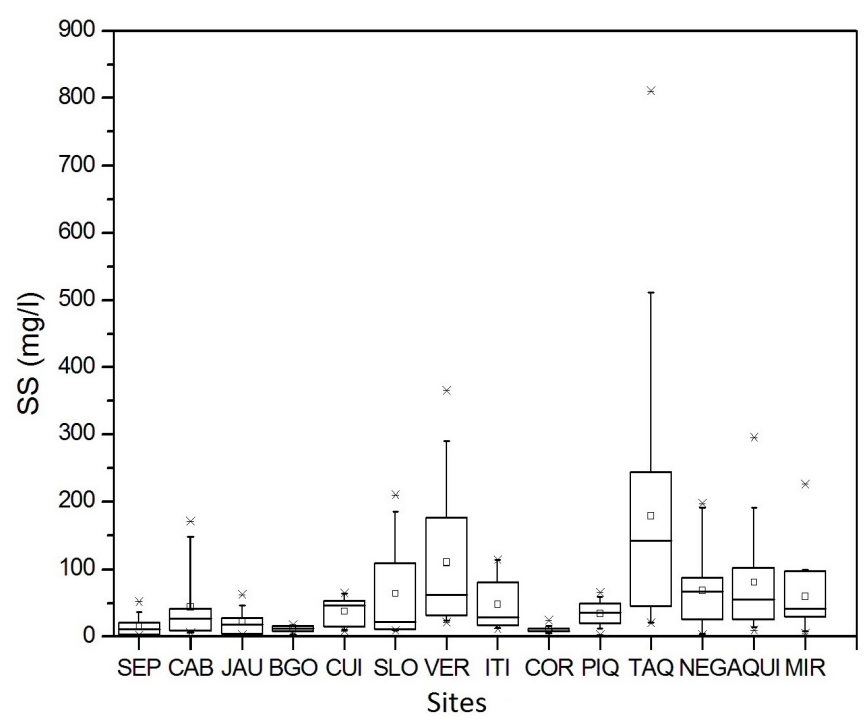

Figure 4. Concentrations of suspended solids (SS) in tributaries of the Paraguay River, estimated twice per year from 2000-2007. has high SS concentrations, reaching a maximum of $206 \mathrm{mg} / \mathrm{L}$ (LARAQUE et al., 2013).

Rivers with high SS concentrations also had relatively high concentrations of total iron, above $2 \mathrm{mg} / \mathrm{L}$ with a maximum concentration of $3.8 \mathrm{mg} / \mathrm{L}$ (Table 3). High concentrations of total iron can also be attributed to high dissolved iron concentrations in groundwater of the Fraturado Centro-Sul aquifer, which discharges into the São Lourenço and Vermelho rivers.

\section{Hydrological transport of major solutes, nutrients, and suspended solids by the tributaries}

The major sources of river water from the plateau areas come from the upper Paraguay River including its tributaries, the Jauru and Sepotuba rivers, which together represent a third of the river inputs into the Pantanal (ANA, 2017). That basin plus the Cuiabá, São Lourenço and Piquiri rivers contribute $72 \%$ of the total river water entering the Pantanal (Table 3). Descriptions of these tributary basins are provided in Item 2 .

Considering individual tributaries, the Sepotuba, Cuiabá and Taquari rivers, with mean discharges of 234, 347, and $355 \mathrm{m3} / \mathrm{s}$, respectively, furnish on average nearly half of the river water entering the Pantanal from the plateau areas (Figure 1, Table 3). The Bento Gomes, Cabaçal, Correntes, Piquiri, Itiquira and Negro rivers each contribute less than $5 \%$ for a total of $17 \%$ of the river water entering the Pantanal. The remaining 33\% of river inflows come from the Jauru, São Lourenço, Vermelho, Miranda and Aquidauana rivers, whose discharges range from $93-166 \mathrm{~m}^{3} / \mathrm{s}$.

With a mean total discharge of approximately $2,100 \mathrm{~m}^{3} / \mathrm{s}$, together the tributaries draining the plateau areas transported massive quantities of solutes, nutrients, and suspended solids into the Pantanal (Table 3). Of the 5,830 t/d of solutes flowing into the Pantanal, dominated by the bicarbonate ion $\left(\mathrm{HCO}_{3}^{-}\right), 34 \%$ came from the Upper Paraguay River basin and 29\% from the Miranda River basin (the latter contributing only $10 \%$ of the discharge). The São Lourenço, Piquiri and Taquari rivers each brought 3-8\% of the solute load. The individual rivers with the highest solute loads were the Miranda and Cuiabá, and those with the lowest loads were the Negro and Correntes rivers. River loads of silica were proportional to discharge and highest in the upper Paraguay and Taquari rivers (Figure 2), whereas the total iron loads were highest in the São Lourenço and Taquari rivers.

On average, the tributaries transported a total of $500 \mathrm{t} / \mathrm{d}$ of POC and $855 \mathrm{t} / \mathrm{d}$ of DOC to the Pantanal. The Taquari River carried the highest POC load (181 t/d, 37\% of the total inputs), followed by the upper Paraguay River (24\%) and the São Lourenço river $(20 \%)$. The Cuiabá River only accounted for $5 \%$ of the total POC load. The upper Paraguay, Cuiabá and Taquari rivers carried the largest DOC loads, exceeding $100 \mathrm{t} / \mathrm{d}$, whereas the smallest loads came from the Bento Gomes and Negro rivers.

The tributaries transported a total of $77 \mathrm{t} / \mathrm{d}$ of TN, $58 \%$ of which came from the upper Paraguay and Taquari rivers and 27\% from the Cuiabá and São Lourenço rivers (Table 3). The Taquari, Cuiabá and Sepotuba were the individual rivers with the largest TN loads, carrying 15, 11, and $10 \mathrm{t} / \mathrm{d}$, respectively, whereas the Bento Gomes, Itiquira, Piquiri, Correntes and Negro rivers each 
Oliveira et al.

Table 3. Mean annual riverine loads ( $\mathrm{t} / \mathrm{d}$ ), including contribution from each subregion ( $\%$ of total river loading), sum of tributary loads, and outflowing load carried by the Paraguay River at Porto Esperança (RP-PE).

\begin{tabular}{|c|c|c|c|c|c|c|c|c|c|c|c|c|}
\hline \multirow{2}{*}{ Regions } & \multirow{2}{*}{ Site } & \multirow{2}{*}{$\begin{array}{c}\mathrm{Q} \\
\mathrm{m} 3 / \mathrm{s}\end{array}$} & DS & $\mathrm{Si}$ & POC & DOC & TN & TDN & TP & DP & SS & Fe'T \\
\hline & & & \multicolumn{10}{|c|}{$\mathrm{t} / \mathrm{d}$} \\
\hline Upper & SEP & 233.46 & 365.19 & 82.00 & 17.65 & 89.62 & 9.71 & 1.29 & 0.46 & 0.11 & 395.00 & 11.20 \\
\hline \multirow[t]{5}{*}{ Paraguay $^{*}$} & $\mathrm{CAB}$ & 79.86 & 504.42 & 49.30 & 7.83 & 36.25 & 4.41 & 0.82 & 0.42 & 0.15 & 502.00 & 11.30 \\
\hline & RP-CA & 548.82 & $1,543.9$ & 208.28 & 107.60 & 187.99 & 23.00 & 3.54 & 1.86 & 0.47 & $1,424.70$ & 51.65 \\
\hline & JAU & 119.24 & 654.00 & 58.80 & 11.23 & 63.72 & 4.48 & 0.77 & 0.45 & 0.16 & 202.00 & 8.40 \\
\hline & $\mathrm{BGO}$ & 17.29 & 89.96 & 9.30 & 0.42 & 16.10 & 1.05 & 0.05 & 0.10 & 0.04 & 11.00 & 1.70 \\
\hline & $\%$ & 32.59 & 33.68 & 35.26 & 23.83 & 31.33 & 36.93 & 26.93 & 31.02 & 32.94 & 10.93 & 21.39 \\
\hline \multirow[t]{2}{*}{ Cuiabá } & CUI & 346.66 & $1,299.56$ & 76.50 & 25.28 & 192.44 & 11.01 & 2.05 & 1.00 & 0.30 & 654.00 & 20.60 \\
\hline & $\%$ & 16.48 & 19.30 & 9.76 & 5.05 & 22.51 & 14.25 & 12.66 & 12.87 & 14.75 & 4.36 & 7.14 \\
\hline \multirow[t]{3}{*}{ São Lourenço } & SLO & 123.87 & 180.56 & 31.60 & 36.58 & 44.14 & 3.98 & 1.12 & 0.44 & 0.10 & 965.00 & 23.70 \\
\hline & VER & 165.46 & 343.21 & 55.20 & 61.17 & 50.68 & 5.74 & 1.89 & 0.50 & 0.15 & $1,969.00$ & 48.00 \\
\hline & $\%$ & 13.76 & 7.78 & 11.07 & 19.54 & 11.09 & 12.58 & 18.59 & 11.58 & 12.29 & 19.58 & 24.84 \\
\hline \multirow[t]{4}{*}{ Piquiri } & ITI & 65.57 & 85.01 & 26.89 & 10.53 & 28.47 & 1.51 & 0.18 & 0.15 & 0.04 & 372.58 & 6.14 \\
\hline & COR & 80.32 & 47.95 & 7.53 & 7.77 & 16.96 & 1.22 & 0.31 & 0.10 & 0.02 & 75.49 & 1.66 \\
\hline & PIQ & 38.30 & 71.91 & 16.75 & 12.01 & 26.03 & 1.85 & 0.33 & 0.15 & 0.02 & 196.33 & 8.18 \\
\hline & $\%$ & 8.76 & 3.04 & 6.53 & 6.06 & 8.36 & 5.93 & 5.06 & 5.15 & 3.67 & 4.30 & 5.53 \\
\hline \multirow[t]{3}{*}{ Taquari } & TAQ & 354.52 & 565.43 & 182.43 & 181.21 & 128.88 & 14.69 & 3.85 & 1.79 & 0.32 & $7,485.05$ & 78.13 \\
\hline & NEG & 27.62 & 45.80 & 8.99 & 4.37 & 14.20 & 1.17 & 0.28 & 0.10 & 0.02 & 186.51 & 2.99 \\
\hline & $\%$ & 18.17 & 9.08 & 24.42 & 37.09 & 16.74 & 20.53 & 25.51 & 24.33 & 16.71 & 51.20 & 28.10 \\
\hline \multirow[t]{3}{*}{ Miranda } & $\mathrm{AQU}$ & 122.37 & 539.81 & 59.35 & 29.92 & 55.10 & 4.36 & 1.15 & 0.71 & 0.27 & $1,066.45$ & 22.95 \\
\hline & MIR & 93.21 & $1,266.28$ & 42.30 & 12.25 & 30.04 & 3.20 & 0.67 & 0.46 & 0.13 & 374.85 & 14.60 \\
\hline & $\%$ & 10.25 & 26.82 & 12.97 & 8.43 & 9.96 & 9.78 & 11.24 & 15.04 & 19.65 & 9.62 & 13.01 \\
\hline $\begin{array}{l}\sum \text { Total inflow } \\
\text { from plateau }\end{array}$ & & $2,103.30$ & $6,447.10$ & 784.24 & 500.30 & 854.70 & 77.27 & 16.18 & 7.76 & 2.03 & $14,983.83$ & 288.69 \\
\hline Paraguay River & & $1,876.00$ & $8,003.23$ & 800.81 & $252.89=$ & $1,274.16$ & 98.90 & 14.59 & 8.11 & 3.24 & $3,306.99$ & 270,70 \\
\hline
\end{tabular}

\footnotetext{
* Upper Paraguay = RP-CA (Paraguay River, Cáceres) + JAU + BGO. Q= discharge, DS= dissolved Solute, $\mathrm{Si}=\mathrm{Silica}, \mathrm{Fe} T=$ total iron, $\mathrm{POC}=$ particulate organic carbon, $\mathrm{DOC}=$ dissolved organic carbon, $\mathrm{TN}=$ Total nitrogen, $\mathrm{TDN}=$ total dissolved nitrogen, $\mathrm{TP}=$ total phosphorus, $\mathrm{DP}=$ dissolved reactive $\mathrm{phosphorus,}$ $\mathrm{SS}=$ suspended solids.
}

brought less than $1.5 \mathrm{t} / \mathrm{d}$. Loads of TDN showed similar patterns, being largest in the Cuiabá and Taquari rivers.

The tributaries transported a total of $8 \mathrm{t} / \mathrm{d}$ of TP and $2 \mathrm{t} / \mathrm{d}$ of DP from the plateau areas to the Pantanal, with the largest contributions from the upper Paraguay, Taquari and Miranda rivers and the lowest from the Piquiri River (Table 3). The Cuiabá, Taquari and Aquidauana rivers had the highest PT loads. Moreira et al. (2005), Moreira et al. (2007), and Silva et al. (2007) also reported concentrations of these nutrients in the Jauru, Cabaçal, Sepotuba, Cuiabá, São Lourenço, Correntes and Piquiri rivers.

The total load of SS brought to the Pantanal by the tributaries was $14,983 \mathrm{t} / \mathrm{d}$ (Table 3). Despite only contributing $18 \%$ of the inflowing water, the Taquari River region accounted for $51 \%$ of the inputs, mostly via the Taquari River itself because the Negro River carried much lower discharge and SS loads.

The tributaries of the São Lourenço region carried 14\% of the inflowing discharge and $20 \%$ of the SS load. Together these two regions accounted for $71 \%$ of the total SS load.

The average SS load of the Taquari River was 4, 7 and 8 times higher than loads of the Vermelho, Aquidauana, and São Lourenço rivers, respectively; those three rivers carried 900-2,000 t/d of SS. The Correntes, Piquiri, Negro, Jauru, and Bento Gomes rivers each transported less than $200 \mathrm{t} / \mathrm{d}$ of SS.

\section{Mass balances for the Pantanal}

The overflow of the rivers onto the floodplains, mainly during high water levels, is well known in the Pantanal (HAMILTON et al., 1996; PADOVANI, 2010). For example, data in show that the mean annual discharge of the Cuiabá River near its mouth was $17 \%$ lower than the total inflowing discharge (sum of the Cuiabá, São Lourenço, Vermelho, Itiquira, Correntes and Piquiri rivers). The Taquari River, which has no tributaries entering within the floodplain, lost about $19 \%$ of its mean annual inflow discharge. The Miranda River, including its tributary the Aquidauana, lost $16 \%$ of its discharge in its lowermost reaches.

The mass-balance estimates for the Cuiabá, Taquari and Miranda rivers are particularly uncertain because of these losses of water to the floodplain, some of which reaches the Paraguay River without returning to the tributary channels, or returns downstream of the sampling points.

The passage of river water through the floodplains results in sedimentation, accounting for the observed $43-69 \%$ losses of SS among the tributaries. Similar losses were observed for POC and total iron, except in the Miranda River (Table 4). A previous study by Padovani et al. (2005) estimated that the Taquari River loses about $77 \%$ of its SS in its lowermost reach. Other researchers have estimated the total retention of SS within the Pantanal at 
about 50\% based on data from 1977-1996 (SEMMELMANN et al., 1996), and 58\% based on data from 1978-2000 (BARBEDO, 2003). It is important to note that these studies varied in the methods of sampling and analysis of SS as well as the frequency and hydrological phases of the sampling.

With the exception of retention of SS and POC on the floodplains, the mass balances for the other parameters showed little differences between the inputs to and outflow from the Pantanal, as indicated by Predicted:Observed ratios near unity
(Table 4). There are no significant urban areas or other sources of anthropogenic pollution within the Pantanal, and therefore the balances reflect natural hydrological and biogeochemical processes. Many processes could potentially alter the balance of nutrients and other reactive solutes, yet their net effects are evidently not large enough to cause major imbalances between inputs and outflows.

The water balance shows a $11 \%$ net loss of water within the Pantanal (Table 5), similar to the $8 \%$ loss estimated by Hamilton et al. (1997) based on the total tributary inputs, the outflow at Porto

Table 4. Comparison between river discharges $\left(\mathrm{m}^{3} / \mathrm{s}\right.$ ) and the loads (discharge-weighted means, $\mathrm{t} / \mathrm{d}$ ) of solutes, nutrients and suspended solids from the Cuiabá, Taquari and Miranda rivers at the upland plateau and lowland floodplain sampling points. P:O = ratio between predicted and observed loads, where predicted loads assume conservative behavior between river inflows and the outflow at the river mouth (loading by rainfall onto the floodplain not included).

\begin{tabular}{|c|c|c|c|c|c|c|c|c|c|c|}
\hline \multirow{2}{*}{ Variables } & & \multicolumn{3}{|c|}{ Cuiabá River } & \multicolumn{3}{|c|}{ Taquari River } & \multicolumn{3}{|c|}{ Miranda River } \\
\hline & & Input & Outflow & P:O & Input & Outflow & P:O & Input & Outflow & P:O \\
\hline Q & $\mathrm{m} 3 / \mathrm{s}$ & 820.2 & 682.8 & 1.2 & 382.1 & 308.9 & 1.2 & 215.6 & 181.7 & 1.2 \\
\hline DS & $t / d$ & $1,692.6$ & $1,371.7$ & 1.2 & 481.7 & 477.0 & 1.0 & $1,692.2$ & $1,754.0$ & 1.0 \\
\hline $\mathrm{Si}$ & $t / d$ & 214.8 & 181.9 & 1.2 & 182.4 & 132.6 & 1.4 & 101.6 & 117.6 & 0.9 \\
\hline POC & $t / d$ & 153.3 & 95.3 & 1.6 & 181.2 & 58.3 & 3.1 & 42.2 & 24.6 & 1.7 \\
\hline DOC & $t / d$ & 358.7 & 372.2 & 1.0 & 128.9 & 124.4 & 1.0 & 85.1 & 77.6 & 1.1 \\
\hline $\mathrm{TN}$ & $t / d$ & 25.3 & 30.3 & 0.8 & 14.7 & 10.6 & 1.4 & 7.6 & 9.5 & 0.8 \\
\hline TDN & $t / d$ & 5.9 & 5.7 & 1.0 & 3.9 & 2.9 & 1.3 & 1.8 & 1.6 & 1.1 \\
\hline $\mathrm{TP}$ & $t / d$ & 2.3 & 2.4 & 1.0 & 1.8 & 1.9 & 1.0 & 1.2 & 1.2 & 1.0 \\
\hline DP & $t / d$ & 0.6 & 0.7 & 0.9 & 0.3 & 0.4 & 0.7 & 0.4 & 0.5 & 0.8 \\
\hline SS & $t / d$ & $4,232.5$ & $2,417.4$ & 1.8 & $7,485.1$ & $2,287.8$ & 3.3 & $1,441.3$ & 670.7 & 2.1 \\
\hline $\mathrm{Fe} T$ & $t / d$ & 108.4 & 47.3 & 2.3 & 78.1 & 44.2 & 1.8 & 37.5 & 39.8 & 0.9 \\
\hline
\end{tabular}

$\mathrm{Q}=$ discharge, $\mathrm{DS}=$ dissolved Solute, $\mathrm{Si}=$ Silica, $\mathrm{FeT}=$ total iron, $\mathrm{POC}=$ particulate organic carbon, $\mathrm{DOC}=$ dissolved organic carbon, $\mathrm{TN}=\mathrm{Total}$ nitrogen, $\mathrm{TDN}=$ total dissolved nitrogen, $\mathrm{TP}=$ total phosphorus, $\mathrm{DP}=$ dissolved reactive phosphorus, $\mathrm{SS}=$ suspended solids.

Table 5. Annual mass balances of major solutes, nutrients, and suspended solids, expressed as mean annual discharge-weighted mean concentrations (mg/L) and loads ( $\mathrm{t} / \mathrm{y})$, for the Pantanal. The input is the sum of mass inputs by inflowing rivers and rainfall. The outflow is the total annual load of the Paraguay River in Porto Esperança (site RP-PE). P:O = ratio of predicted to observed loads at Porto Esperança, where the predicted load assumes no net gain or loss as water moves through the Pantanal.

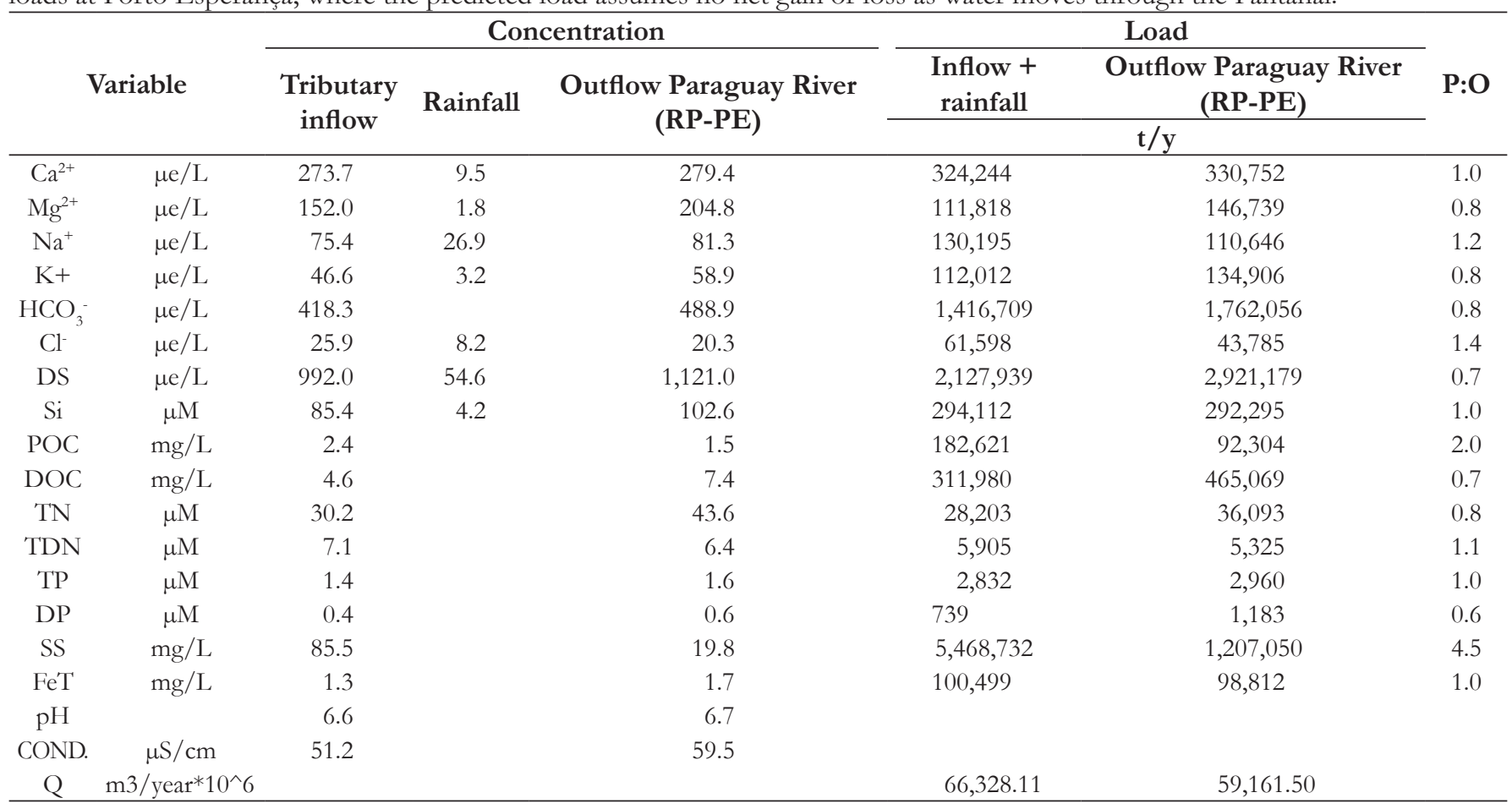


Esperança, and the balance between rainfall on and evapotranspirative losses from the inundated floodplains. Although the major river inputs were included, those authors noted that the rainfall and evapotranspiration estimates were very uncertain, yet important, terms in the water budget. Penatti et al. (2015) provides further analysis of the rainfall and evapotranspiration for the region. Groundwater-surface water exchanges have little effect on the water budgets at these large spatial scales (HAMILTON et al., 1997; GIRARD; NUNES DA CUNHA, 1999).

As was observed for the Cuiabá, Taquari, and Miranda rivers, the annual mass balances for the majority of the major solutes showed P:O ratios close to unity for the entire Pantanal, indicating no major net losses or gains as water moves through the floodplains (Table 5). Only large departures from unity (i.e., more than $\pm 20 \%$ ) are considered as evidence for net losses or gains because of the indeterminate-but likely large - uncertainty in these estimates. Hamilton et al. (1997) reported similar findings for the major solutes based on a preliminary analysis, except that their analysis showed high $\mathrm{P}: \mathrm{O}$ ratios for $\mathrm{Cl}^{-}$and $\mathrm{SO}_{4}^{2-}$, indicating net retention. The present study lacks $\mathrm{SO}_{4}{ }^{2-}$ data, but the high $\mathrm{P}: \mathrm{O}$ for $\mathrm{Cl}^{-}$(1.4) suggests net retention (Table 5).

The mass-balance evidence in this study for net changes in dissolved nutrient loads is equivocal; low $\mathrm{P}: \mathrm{O}$ ratios suggesting net gains were observed for DP (0.6) and DOC (0.7), whereas a P:O ratio close to unity was found for TDN (1.1) (Table 5).

In contrast, as shown clearly in Table 5 and in agreement with studies of river sediment loads cited above, sedimentation within the Pantanal appears to result in net retention of a substantial fraction of inflowing SS (P:O 4.5) and particulate organic matter (P:O 2.0). Retention of particulate matter is expected when river waters pass through relatively quiescent floodplain areas. Similar retention of the majority of SS and about half of the POC was also observed for the Cuiabá, Taquari, and Miranda rivers.

In spite of the high degree of river-floodplain exchange in the Pantanal compared to other large river systems and the evidence for substantial sedimentation losses of particular matter, most solutes show relatively conservative behavior on a landscape scale (i.e., P:O ratios close to unity). This seemingly conservative behavior was not expected because many biogeochemical processes could potential alter concentrations of the nutrients and most of the major solutes, including nutrient assimilation by primary production and liberation by decomposition, sediment-water exchanges, denitrification, formation and dissolution of minerals, and oxidation-reduction reactions associated with the depletion of dissolved oxygen in floodplain waters. The apparent balance between inputs and outflow for most solutes suggests either that these processes do not have major effects on transport, or that losses and gains are in approximate equilibrium at the landscape scale in waters of the Pantanal.

\section{Human impacts on mass balances}

The environmental impacts of human activities in and around the Pantanal include hydroelectric dams, with 45 now in operation and many more proposed or in construction. Although many of these dams are small run-of-river designs, they fragment the rivers, blocking migrations of fishes, and potentially alter the natural fluxes of sediments and nutrients. The potential impacts of these dams on the hydro-ecological functioning of the Pantanal are discussed by Zeilhofer and Moura (2009), Calheiros and Oliveira (2010), Calheiros et al. (2012), Fantin Cruz et al. (2015), and Fantin Cruz et al. (2016). For example, the Ponte de Pedra reservoir significantly reduced concentrations of suspended sediments, total $\mathrm{P}$, and nitrate in the Correntes River as a result of sedimentation and, in the case of nitrate, biological uptake (FANTIN-CRUZ et al., 2016).

These run-of-river dams can retain up to $66 \%$ of the particulate organic matter load, which could amount to $\sim 52 \%$ of the overall tributary loading to the Pantanal (SOUZA FILHO, 2013). Although more research on sediment retention is needed, these kinds of dams may also retain a significant fraction of the coarse sediments transported as bedload. Such sediment retention could counterbalance increased sediment inputs by enhanced rates of soil erosion caused by changes in land use (PADOVANI et al., 2005; SOUZA FILHO, 2013), but strongly diminished sediment loads of tributaries entering the Pantanal could result in sediment starvation and geomorphological changes.

Considering that approximately 135 new hydroelectric dams could potentially be constructed in the basins surrounding the Pantanal, in addition to the existing, the natural fluxes of sediments and nutrients are likely to change in the future, with uncertain consequences for floodplain productivity, including terrestrial pastures as well as the aquatic biota. Extensive grazing of livestock on native pastures as well as commercial, recreational, and artisanal fisheries provide important economic and social services in the region.

\section{CONCLUSIONS}

The water balance for the Pantanal showed a modest reduction $(11 \%)$ between river inflows plus rainfall and the outflow, although other studies have indicated that rainfall and evapotranspiration within the floodplains are of similar magnitudes to river inflows and outflow on the scale of the entire Pantanal (HAMILTON et al., 1997; PENATTI et al., 2015). Most major solutes as well as total iron showed no evidence for large losses or gains as water moves through the Pantanal, whereas dissolved $\mathrm{N}$ and $\mathrm{P}$ showed evidence for net gains. In contrast, suspended sediments and particulate organic carbon showed net retention, presumably due to sedimentation as river waters passes though the floodplains.

The upper Paraguay River and Taquari River regions contributed the most water as well as silica, TN, TDN, TP and POC to the Pantanal. Silica loads were directly proportional to discharge. The Taquari and São Lourenço River regions contributed the most of SS. Miranda River contributed the most of DS and DP loads although they brought only $\sim 10 \%$ of the discharge. Total iron loads were highest in São Lourenço and Taquari regions.

The individual rivers that transported the highest loads of major solutes were the Miranda e Cuiabá, whereas the highest loads of SS and COP came from the Taquari and Vermelho rivers. Taquari and Cuiaba rivers transported highest loads of nitrogen and phosphorus. 
Mass balances of major solutes, nutrients and particulate matter as water moves through the floodplains of the Pantanal (Paraguay River, Brazil)

\section{ACKNOWLEDGEMENTS}

The Brazilian Conselho Nacional de Pesquisa (CNPq) provided financial support for this research through its Long-term Ecological Research Program (PELD) (Processo 520056/98-1). The Brazilian Corporation for Agricultural Research (Embrapa Pantanal) provided logistical and personnel support, and we particularly acknowledge the assistance of our colleagues Valdomiro Lima e Silva, Isaac Teixeira, Maria Davina dos Santos, Valdete Sanchez, Egídia do Amaral, Josias Campos Oliveira, and Antônio Arantes Sobrinho, as well as a number of visiting students and researchers at the Limnology Laboratory of Embrapa Pantanal.

\section{REFERENCES}

ABREU, C. A. A. Dinâmica do Carbono Orgânico Total no Rio Cuiabá - Mato Grosso. 2016. 45 f. Dissertação (Mestrado em Recursos Hídricos) - Universidade Federal de Mato Grosso, Cuiabá, 2016.

AGÊNCIA NACIONAL DE ÁGUAS - ANA. Plano de Recursos Hídricos da Região Hidrográfica do Paraguai - PRH PARAGUAI. Produto Parcial PP-02. Diagnóstico consolidado da região hidrográfica do rio Paraguai. Brasília: ENGECORPS ENGENHARIA S.A., 2017. p. 374.

ANEEL - AGÊNCIA NACIONAL DE ENERGIA ELÉTRICA. Banco de Informações de Geração. 2016. Disponível em: www.aneel. gov.br/aplicacoes/capacidadebrasil/capacidadebrasil.cfm. Acesso em: DIA MÊS ANO.

APHA - American Public Health Association. AWWA - American Water Works Association. WEF - Water Environmental Federation. Standard Methods for the Examination of Water and Wastewater. Washington: APHA, 2005. (21th ed., p. 1268).

ASSINE, M. L. River avulsions on the Taquari megafan: Pantanal wetland, Brazil. Geomorphology, v. 70, n. 3-4, p. 357-371, 2005. http://dx.doi.org/10.1016/j.geomorph.2005.02.013.

ASSINE, M. L.; SOARES, P. C. Quaternary of the Pantanal, Westcentral Brazil. Quaternary International, v. 114, n. 1, p. 23-24, 2004. http://dx.doi.org/10.1016/S1040-6182(03)00039-9.

BARBEDO, A. G. A. Estudo Hidrossedimentológico na Bacia do Alto Paraguai - Pantanal. 2003. 107 f. Dissertação (Mestrado em Saneamento Ambiental e Recursos Hídricos) - Universidade Federal de Mato Grosso do Sul, Campo Grande, 2003.

BASTVIKEN, D.; SANTORO, A. L.; MAROTTTA, H.; PINHO, L. Q.; CALHEIROS, D. F.; CRILL, P.; ENRICH-PRAST, A. Methane Emissions from Pantanal, South America, during the Low Water Season: Toward More Comprehensive Sampling. Environmental Science \& Technology, v. 44, n. 14, p. 5450-5455, 2010. http://dx.doi. org/10.1021/es1005048. PMid:20568738.
BENNER, R.; STROM, M. A critical evaluation of the analytical blank associated with DOC measurements by high temperature catalytic oxidation. Marine Chemistry, v. 41, n. 1-3, p. 153-160, 1993. http://dx.doi.org/10.1016/0304-4203(93)90113-3.

BERGIER, I.; ASSINE, M. L.; MCGLUE, M. M.; ALHO, C. J. R.; SILVA, A.; GUERREIRO, R. L.; CARVALHO, J. C. Amazon rainforest modulation of water security in the Pantanal wetland. The Science of the Total Environment, v. 619-620, p. 1116-1125, 2018. http://dx.doi.org/10.1016/j.scitotenv.2017.11.163. PMid:29734590.

CALHEIROS, D. F. Influência do pulso de inundação na composição isotópica ( $\delta 13$ C e $\delta 15 \mathrm{~N}$ ) das fontes primárias de energia na planície de inundação do rio inundação do rio Paraguai (Pantanal-MS). 2003. 186 f. Tese (Doutorado em Energia Nuclear na Agricultura) - Centro de Energia Nuclear na Agricultura/Universidade de São Paulo, Piracicaba, 2003.

CALHEIROS, D. F.; HAMILTON, S. K. Limnological conditions associated with natural fish kills in the Pantanal Wetland of Brazil. Verh Internat Verein Limnol, v. 26, p. 2189-2193, 1998.

CALHEIROS, D. F; OLIVEIRA, M. D.; PADOVANI, C. R. Hydro-ecological Processes and Anthropogenic Impacts on the Pantanal Wetland. In: IORIS, A. A. R. (ed.). Tropical Wetland Management: The South-American Pantanal and the International Experience. Farnham: Ashgate, 2012. p. 29-57.

CALHEIROS, D. F.; OLIVEIRA, M. D. O rio Paraguai e sua planície de inundação: o Pantanal Mato-Grossense. Ciência e Ambiente, n. 14. p. 113-130. 2010.

CASONATTO, A. E. Efeito da formação do reservatório da APM Manso sobre a qualidade da água do rio Cuiabá. 2015. 49 f. Trabalho de Conclusão de Curso (Graduação em Engenharia Sanitaria e Ambiental) -Universidade Federal de Mato Grosso, Cuiabá, 2015.

CORREIA, R. Utilização de dados topo-batimétricos para a modelagem bidrodinâmica 1d com apoio de um sistema de informações geográficas estudo de caso do rio Paraguai. 2016. Dissertação (Mestrado Engenharia de Recursos Hídricos e Ambiental) - Universidade Federal do Paraná, Curitiba, 2016.

CUNHA, D. G. F.; BOTTINO, F.; CALIJURI, M. C. Land use influence on eutrophication-related water variables: case study of tropical rivers with different degrees of anthropogenic interference. Acta Limnologica Brasiliensia, v. 22, n. 1, p. 35-45, 2010. http:// dx.doi.org/10.4322/actalb.02201005.

DALMAGRO, H. J.; JOHNSON, M. J.; LATHUILLIÈRE, M. S.; PINTO JUNIOR O. B.; COUTO, E. G. Dissolved organic carbon quality assessed along the Cuiabá river of Mato Grosso, Brazil, using fluorescence spectroscopy. In: AMERICAN GEOPHYSICAL UNION, FALL MEETING, 2013, San Francisco. Proceedings... San Francisco: AGU, 2013. 
DEPETRIS, P. J.; PAOLINI, J. Biogeochemical aspects of South American rivers: the Parana and the Orinoco. In: DEGENS, E.T.; KEMPE, S.; RICHEY, J. E. (eds) Biogeochemistry of Major World Rivers. Chichester: John Wiley \& Sons, 1991. p. 105-125.

FANTIN-CRUZ, I.; PEDROLLO, O.; GIRARD, P.; ZEILHOFER, P.; HAMILTON, S. K. Effects of a diversion hydropower facility on the hydrological regime of the Correntes River, a tributary to the Pantanal floodplain, Brazil. Journal of Hydrology (Amsterdam), v. 531, n. 3, p. 810-820, 2015. http://dx.doi.org/10.1016/j. jhydrol.2015.10.045.

FANTIN-CRUZ, I.; PEDROLLO, O.; GIRARD, P.; ZEILHOFER, P.; HAMILTON, S. K. Changes in river water quality caused by a diversion hydropower dam bordering the Pantanal floodplain. Hydrobiologia, v. 768, n. 1, p. 223-238, 2016. http://dx.doi. org/10.1007/s10750-015-2550-4.

GALDINO, S. Estimativa da perda de terra sob pastagens cultivadas em solos arenosos da bacia bidrográfica do Alto Taquari-MS/MT. 2012. 115 p. Tese (Doutorado em Engenharia Agrícola) - Programa de Pós-Graduação em Engenharia Agrícola da UNICAMP, Campinas, 2012.

GIRARD, P.; NUNES DA CUNHA, C. Relationship between surface and groundwater during the flood in the Brazilian Pantanal. Revista Boliviana de Ecologia y Conservación Ambiental, v. 6, p. 33-40, 1999.

HAMILTON, S. K., et al. 1999. Chemical characteristics of Pantanal waters. In: SYMPOSIUM ON NATURAL AND SOCIOECONOMIC RESOURCES OF THE PANTANAL: MANAGEMENT AND CONSERVATION, 2., 1996, Corumbá, Proceedings... Brasília: Brazilian Corporation for Agricultural Research, 1999. p. 89-100.

HAMILTON, S. K.; SIPPEL, S. J.; CALHEIROS, D. F.; MELACK, J. M. An anoxic event and other biogeochemical effects of the Pantanal wetland on the Paraguay River. Limnology and Oceanography, v. 42, n. 2, p. 257-272, 1997. http://dx.doi.org/10.4319/lo.1997.42.2.0257.

HAMILTON, S. K.; SIPPEL, S. J.; MELACK, J. M. Inundation patterns in the Pantanal wetland of South America determined from passive microwave remote sensing. Archiv für Hydrobiologie, v. 137, p. 1-23, 1996.

HAMILTON, S. K.; SIPPEL, S. J.; MELACK, J. M. Oxygen depletion and carbon dioxide and methane production in waters of the Pantanal wetland of Brazil. Biogeochemistry, v. 30, n. 2, p. 115-141, 1995. http://dx.doi.org/10.1007/BF00002727.

HONÓRIO, B.A.D.; HORBE, A.M.C.; SEYLER, P. Chemical composition of rainwater in western Amazonia - Brazil. Atmospheric Research, v. 98, n. 2-4. p. 416-425, 2010.

Instituto SOS Pantanal; WWF-Brasil - World Wide Fund for Nature. Monitoramento das alterações da cobertura vegetal e uso do Solo na Bacia do Alto Paraguai - Porção Brasileira. Período de análise: 2012-2014. Brasília: WWF-Brasil, 2015.

JOHNSON, M. S.; COUTO, E. G.; PINTO JUNIOR, O. B.; MILESI, J.; SANTOS AMORIM, R. S.; MESSIAS, I. A. M.; BIUDES, M. S. Soil CO2 dynamics in a tree island soil of the Pantanal: the role of soil water potential. PLoS One, v. 8, n. 6, p. e64874, 2013. http://dx.doi.org/10.1371/journal.pone.0064874.

JUNK, W. J.; BAYLEY, P. B.; SPARKS, R. E. The flood pulse concept in river-floodplain systems. Canadian special publication of fisheries and aquatic sciences, v. 106, p. 110-127, 1989.

JUNK, W. J.; BROWN, M.; CAMPBELL, I. C.; FINLAYSON, M.; GOPAL, B.; RAMBERG, L.; WARNER, B. G. The comparative biodiversity of seven globally important wetlands: a synthesis. Aquatic Sciences, v. 68, n. 3, p. 400-414, 2006. http://dx.doi. org/10.1007/s00027-006-0856-z.

LARAQUE, A.; CASTELLANOS, B.; STEIGER, J.; LÒPEZ, J. L.; PANDI, A.; RODRIGUEZ, M.; ROSALES, J.; ADĖLE, G.; PEREZ, J.; LAGANE, C. A. Comparison of the suspended and dissolved matter dynamics of two large inter-tropical rivers draining into the Atlantic Ocean: the Congo and the Orinoco. Hydrological Processes, v. 27, n. 15, p. 2153-2170, 2013. http://dx.doi. org/10.1002/hyp.9776.

LIENGAARD, L.; PETER NIELSEN, L.; REVSBECH, N.P.; PRIEMÉ, A.; ELBERLING, B.; ENRICH-PRAST, A.; KÜHL, M. Extreme emission of N2O from tropical wetland soil (Pantanal, South America). Frontiers in Microbiology, v. 3, n. 433, p. 132-144, 2013.

LIMA, C.; ZEILHOFER, P.; DORES, E.; CRUZ, I. Variabilidade espacial da Qualidade de Água em Escala de Bacias - Rio Cuiabá e São Lourenço, Mato Grosso. Revista Brasileira de Recursos Hídricos, v. 20, n. 1, p. 169-178, 2015. http://dx.doi.org/10.21168/rbrh. v20n1.p169-178.

LIMA, E. B. N. R. Modelação integrada para gestão da qualidade da água na bacia do rio Cuiabá. 2010. 206 f. Tese (Mestrado em Engenharia) - Universidade Federal do Rio de Janeiro, Rio de Janeiro, 2010.

MACKERETH, J. F. H.; HERON, J.; TALLING, J. F. Water analysis: some revised methods for limnologists. Freshwater Biological Association, n. 36, p. 121, 1978.

MORA, A.; LARAQUE, A.; MOREIRA-TURCQ, P.; ALFONSO, J. A.Temporal variation and fluxes of dissolved and particulate organic carbon in the Apure, Caura and Orinoco rivers, Venezuela. Journal of South American Earth Sciences, v. 54, p. 47-56, 2014. http:// dx.doi.org/10.1016/j.jsames.2014.04.010.

MOREIRA, M.M.; BARRETO, R; SILVA, E.L.V.; OLIVEIRA, M.D.; CALHEIROS, D.F. Aporte para o Pantanal de Nutrientes e Sólidos Suspensos provenientes dos rios Cuiabá e São Lourenço, 
Mass balances of major solutes, nutrients and particulate matter as water moves through the floodplains of the Pantanal (Paraguay River, Brazil)

Mato Grosso-Brasil. In: CONGRESSO DE ECOLOGIA DO BRASIL, 7., 2005, Caxambu. Anais... São Paulo: SEB, 2005.

MOREIRA, M. M.; CHAVEZ, R. M. L.; SILVA, E. L. V.; BARRETO, R.; SILVA, F. A. V.; BARROS, L. F.; BARBOSA, D. S.; OLIVEIRA, M. D.; CALHEIROS, D. F. Caracterização Limnológica dos rios Correntes e Piquiri (MT) em área de planalto e aporte de nutrientes e sólidos suspensos para o Pantanal. In: CONGRESSO DE ECOLOGIA DO BRASIL, 8., 2007, Caxambu. Anais... Caxambu: SEB, 2007.

MOREIRA-TURCQ, P.; SEYLER, P.; GUYOT, J. L.; ETCHEBER, H. Exportation of organic carbon from the Amazon River and its main tributaries. Hydrological Processes, v. 17, n. 7, p. 1329-1344, 2003. http://dx.doi.org/10.1002/hyp.1287.

OLIVEIRA, M. D.; CALHEIROS, D. F. Transporte de nutrientes e sólidos suspensos na bacia do rio Taquari (Mato Grosso do Sul). Acta Limnologica Brasiliensia, v. 10, n. 2, p. 35-45, 1998.

OLIVEIRA, M. D.; CALHEIROS, D. F.; JACOBI, C. M.; HAMILTON, S. K. Abiotic factors controlling the establishment and abundance of the invasive golden mussel Limnoperna fortunei. Biological Invasions, v. 13, n. 3, p. 17-729, 2011. http://dx.doi. org/10.1007/s10530-010-9862-0.

PADOVANI, C. R. Dinâmica espaço-temporal das inundações no Pantanal. 2010. 175 f. Tese (Doutorado em Ecologia Aplicada) - Escola Superior de Agricultura Luiz de Queiroz, Centro de Energia Nuclear na Agricultura, Piracicaba, 2010.

PADOVANI, C. R.; GALDINO, S.; VIEIRA, L. M. Dinâmica hidrológica e de sedimentação do Rio Taquari no Pantanal. In: GALDINO, S.; VIEIRA, L. M.; PELLEGRIN, L. A. (Ed.). Impactos ambientais e socioeconômicos nas Bacia do rio Taquari - Pantanal. Corumbá: Embrapa Pantanal, 2005. p. 153-162.

PENATTI, N. C.; ALMEIDA, T. I. R.; FERREIRA, L. G.; ARANTES, A. E.; COE, M. T. Satellite-based hydrological dynamics of the world's largest continuous wetland. Remote Sensing of Environment, v. 170, p. 1-13, 2015. http://dx.doi.org/10.1016/j.rse.2015.08.031.

PUPIM, F. N.; BIERMAN, P. R.; ASSINE, L. M.; ROOD, D. H.; SILVA, A.; MERINO, E. R. Erosion rates and landscape evolution of the lowlands of the Upper Paraguay river basin (Brazil) from cosmogenic 10Be. Geomorphology, v. 234, p. 151-160, 2015. http:// dx.doi.org/10.1016/j.geomorph.2015.01.016.

REZENDE FILHO, A. T.; FURIAN, S.; VICTORIA, R. L.; MASCRÉ, C.; VALLES, V.; BARBIERO, L. Hydrochemical variability at the Upper Paraguay Basin and Pantanal wetland. Hydrology and Earth System Sciences, v. 16, n. 8, p. 2723-2737, 2012. http://dx.doi.org/10.5194/hess-16-2723-2012.

SEMMELMANN, F. R.; BORGES, A.; RISSO, A.; BORDAS, M.; LOPES, M. S. Balanço Preliminar de sedimento no Pantanal da bacia do Alto Paraguai-BAP, Brasil. In: SIMPÓSIO SOBRE RECURSOS NATURAIS E SOCIOECONÔMICOS DO
PANTANAL: MANEJO E CONSERVAÇÃO, 2., 1996, Corumbá. Anais... Corumbá: CPAP, 1996. p. 79-87.

SILVA, E. L. V.; MOREIRA, M. M.; BARRETO, R.; BARROS, L. F.; BARBOSA, D. S.; OLIVEIRA, M. D.; CALHEIROS, D. F. Aporte de Nutrientes e sedimentos para o Pantanal - rios Cabaçal, Sepotuba e Jauru (MT). In: CONGRESSO DE ECOLOGIA DO BRASIL, 8., 2007, Camxabu, MG. Anais... São Paulo: SEB, 2007. CD-ROM.

SOUZA, C. F.; ARTHINGTON, A. H.; COLLISCHONN, W. Preliminary assessment of dam hidrological effects in the Brazilian Pantanal. In: INTERNATIONAL SYMPOSIUM ON ECOHYDRAULICS, 7., 2009, Concepcion. Proceedings... Concepcion: IAHR, 2009.

SOUZA, V. F.; SANTORO, A. L.; VAN WEERELT, M.; ENRICHPRAST, A. Sediment denitrification, dnra and anammox rates in tropical floodplain lake (Pantanal, Brazil). Oecologia Australis, v. 16, n. 4, p. 734-744, 2012. http://dx.doi.org/10.4257/oeco.2012.1604.01.

SOUZA FILHO, E. E. As barragens na bacia do rio Paraguai e a possível influência sobre a descarga fluvial e o transporte de sedimentos. Boletim de Geografia, v. 31, n. 1, p. 117-133, 2013.

TEIXEIRA, M. C.; SANTANA, N. F; AZEVEDO, J. C. R.; PAGIORO, T. A. Padrões de variação do carbono orgânico na planície de inundação do rio Paraná. Oecologia Brasiliensis, v. 1, n. 12 , p. $57-65,2008$.

VALDERRAMA, J. C. The simultaneous analyses of TN and TP in natural waters. Marine Chemistry, v. 10, n. 2, p. 109-112, 1981. http://dx.doi.org/10.1016/0304-4203(81)90027-X.

VEGA, L. F.; NUNES DA CUNHA, C.; ROTHAUPT, K.-O.; MOREIRA, M. Z.; WANTZEN, K. M. Does flood pulsing act as a switch to store or release sediment-bound carbon in seasonal floodplain lakes? Case study from the Colombian Orinoco-Llanos and the Brazilian Pantanal. Wetlands, v. 34, n. 1, p. 177-187, 2014. http://dx.doi.org/10.1007/s13157-013-0495-9.

WANTZEN, K. M.; CUNHA, C. N.; JUNK, W. J.; GIRARD, P.; ROSSETTO, O. C.; PENHA, J. M.; COUTO, E. G.; BECKER, M.; PRIANTE, G.; TOMAS, W. M.; SANTOS, S. A.; MARTA, J.; DOMINGOS, I.; SONODA, F.; CURVO, M.; CALLIL, C. Towards a sustainable mangement concept for ecosystem services of the Pantanal wetland. Ecohidrology and Hidrobiology, v. 8, n. 2-4, p. 115-138, 2008. http://dx.doi.org/10.2478/v10104-009-0009-9.

WETZEL, R. G.; LIKENS, G. E. Limnological Analyses. SpringerVerlag, New York, 342 pp. 1991. http:/ /dx.doi.org/10.1007/9781-4757-4098-1.

ZANI, H.; ASSINE, M. L.; SILVA, A.; CORRADINI, F. A.; KUERTEN, S.; GRADELLA, F. S. Geoformas deposicionais 
e feições erosivas no pantanal mato-grossense identificadas por sensoriamento remoto. Geografia, v. 34, p. 643-654, 2009.

ZEILHOFER, P.; FERNANDES, D. C.; OLIVEIRA, M. D.; DORES, E. F. G. C.; LIMA, G. A. R.; FANTIN-CRUZ, I. Temporal patterns of water quality in the Pantanal floodplain and its contributing Cerrado upland rivers: implications for the interpretation of freshwater integrity. Wetlands Ecology and Management, v. 24, n. 6, p. 697-716, 2016. http://dx.doi.org/10.1007/s11273-016-9497-8.

ZEILHOFER, P.; LIMA, E. B. N. R.; LIMA, G. A. R. Spatial patterns of water quality in the Cuiabá river basin, central Brazil. Environmental Monitoring and Assessment, v. 123, n. 1-3, p. 41-62, 2006. http://dx.doi.org/10.1007/s10661-005-9114-4. PMid:17089078.

ZEILHOFER, P.; MOURA, R. M. Hydrological changes in the northern Pantanal caused by the Manso dam: Impact analysis and suggestions for mitigation. Ecological Engineering, v. 35, n. 1, p. 105-117, 2009. http://dx.doi.org/10.1016/j.ecoleng.2008.09.011.

\section{Authors contributions}

All authors have a long history working in the Paraguay River basin for 20 to 30 years.

Marcia Divina de Oliveira: Participated in all phase of the study including planning, data collection and analysis, and manuscript writing.

Debora Fernandes Calheiros: Participated in all phase of the study including planning, data collection and analysis, discussing and reviewing the manuscript.

Stephen Kimber Hamilton: Participated in the study including planning, data analysis, manuscript writing, and translation to English. 